\title{
THE EMERGENCE PROFILE OF TREE THINKING OF SENIOR HIGH SCHOOL STUDENTS THROUGH THE INQUIRY BASED LEARNING MODEL
}

\author{
Era Mutiara ${ }^{1}$, AA Juhanda ${ }^{2}$, Billyardi Ramdhan ${ }^{3}$ \\ Jurusan Pendidikan Biologi, Fakultas Keguruan dan Ilmu Pendidikan, Universitas \\ Muhammadiyah Sukabumi \\ Jalan R. Syamsudin SH No. 50 Kec. Cikole Kota Sukabumi \\ eramutiara1797@gmail.com ${ }^{1}$, aajuhanda@gmail.com², billyardi@ummi.ac.id ${ }^{3}$
}

Doi: https://doi.org/10.31943/mangiferaedu.v5i1.92

Received: April 20, $2020 \quad$ Accepted: July 12, $2020 \quad$ Published: July 31, 2020

Citation: Mutiara, E., Juhanda A., \& Billyardi, B. (2020). The Emergence Profile of Tree Thinking of Senior High School Students Through the Inquiry Based Learning Model. Jurnal Mangifera Edu, 5(1), 18-25.

\begin{abstract}
The use of tree thinking in learning biology is still rarely used. The purpose of this study was to identify the tree thinking emergence profile of senior high school students through the inquiry based learning model. This research is using the experimental method. The approach used in this research is a qualitative approach. The population in this study was 36 students of class $X$ in SMA Negeri Sukabumi. The samples were taken by using a purposive sampling technique. The data collection was performed using a written test in the form of LKS by using five tree thinking indicators. The results showed that the value of tree thinking students for the first indicator gained a percentage of 69\% included in the good category, the second indicator obtained a percentage of $63 \%$ included in the good category, the third indicator received a percentage of $73 \%$ included in the good category, the fourth indicator obtained a percentage of $81 \%$ included in the very category good, and the fifth indicator gets a percentage of $52 \%$ included in the category enough. This result leads to the Student learning outcomes that are categorized as good because the students follow the learning by using models, strategies, and learning approaches that can improve their ability of tree thinking in Arthropoda subjects. This study suggests that the inquiry based learning model can be used as an alternative in learning biology to improve tree thinking skills.
\end{abstract}

Keywords: Tree Thinking, Inquiry-Based Learning Model, Phylogenetic

\section{INTRODUCTION}

The educational context demands that most students are expected to have abilities in several branches of science taught in schools. The 21 st Century science now demands individuals to be quality Human Resources (HR). One of the characteristics of quality human resources is being able to manage, use, and develop thinking skills to become essential (Anjarsari, 2014).

Besides, students are also asked to have the ability to use scientific methods, process skills approach, practical activities, experiments, inquiry, conceptual approaches, and other 
approaches. The scientific method is an essential strategy for students to more easily understand the subject matter. The government is trying to adjust the changing times with the education system in Indonesia. One such effort is that in the curriculum of senior high school biology subjects, there is a basic competency of students to classify living things and understand phylogeneous cladograms/trees. Learning every field or subject in school has a national standard reference in the form of a curriculum package. The curriculum is designed to assist educators in equating perceptions about achieving educational goals and providing guidance contained in the implementation process. The intended direction is in the form of Core Competencies and Basic Competencies, which can be derived into specific learning objectives and indicators to be achieved in each learning activity. Learning in understanding phylogenetic cladograms/trees for high school students is listed in Basic Competency 4.8, namely: "Present reports on the observations and analysis of the picker and phylogenetic and their role in life" (Kemendikbud, 2016).

Tree thinking is an essential ability for scientists, especially in biology and other general public. The use of tree thinking has generated a lot of knowledge and benefits, such as in agriculture, climate change, biotechnology, and health (Novick \& Catley, 2018). Basic understanding related (tree of life) can train students to understand and adapt to social issues that occur in the 21st century (Novick \& Catley, 2013). In a research journal in 2013, there were several abilities of tree thinking more specifically, in identifying clade in the net, evolutionary relationships that explain structural problems, as well as explaining the relationship between the evolution of politics, bifurcus, and understanding convergent evolution (Novick \& Catley, 2016). In Indonesia, learning uses tree thinking, is still very rarely used at the university and secondary schools. Thus students are expected to be able to make phylogenic trees (tree thinking). Phylogenetic trees are learning about kinship relationships and the use of phylogenetic trees to explain evolutionary phenomena (Baum \& Offner, 2008). Phylogenetic tree refers to an evolutionary understanding approach that emphasizes students' making and interpreting phylogenetic tree diagrams. The ability to understand and make phylogenetic tree diagrams is an essential skill for biology students who want to know the ancestral lineage, ancestry, ancestors of an order species and taxa level. The evolutionary history of organisms has been described in the form of branched or "phylogenetic" trees. The phylogenetic tree itself can be interpreted as a visual representation of hypotheses about evolutionary relationships that can be used in biology (Hidayat, 2017).

The phylogenetic tree can be used as a choice for students in learning the classification and lineage of a species or order. Making phylogenetic trees or cladograms 
can also enable the students to illustrate the sequence of branching points based on their phylogeneous analysis (Jones Jr \& Luchsinger, 1986). Phylogenetic trees are also essential for organizing knowledge about biodiversity, and by studying this phylogenetic tree, students can express their hypotheses regarding the evolutionary relationships between taxa in specific groups based on shared characters (Novick \& Catley, 2007). Another understanding of the phylogenetic tree is a diagram that illustrates the evolutionary relationship of the whole organism or group of all organisms, the relationship between these organisms is the relationship seen based on genes or hereditary traits (Wiley \& Lieberman, 2011).

Students' ability to learn tree thinking is expected to make a tree diagram cladogram/phylogenetic tree by using one of the matching methods and making it easier to study phylogenetic trees. By using a learning model, the students are provided many opportunities to search for information and carry out a phased investigation of a subject that wants to be researched or analyzed using the model inquiry-based learning (IBL). The inquiry model identified as a series of learning activities that maximally involve all students' abilities to find and investigate problems systematically, critically, and logically. Inquiry learning emphasizes the thought process and stimulates students to ask questions and carry out examinations, or investigations to improve intellectual skills and student learning activities in the learning process. The purpose of this study is for students to find information and learn a symptom and conduct an investigation and examination of Arthropod material using tree thinking to find out the ancestral lineage of a phylum takasa, group of species, or order. Researchers are interested in knowing the appearance profile tree thinking high school students through the IBL model in Biology subjects even semester semester 2019/2020.

\section{RESEARCH METHOD}

This research utilized a descriptive qualitative method. The approach used in this research is a qualitative approach. As stated by Sudjana, et al., (2007) which explains "descriptive research is research that seeks to describe a phenomenon, event, event that is happening at present". The primary purpose of using descriptive methods, according to Ali (2010) is "to describe the truth of phenomena based on empirical data as an answer to the problem at the time the research was conducted".

The population in this study was 36 students of class X at SMA Negeri Sukabumi. The samples were taken using the purposive sampling technique by taking the subject not 
based on strata, random or region but based on the existence of specific objectives. The research was carried out in the first week of March 2020.

Data collection is done by using a written test. Written test in the form $L K S$ by using five (5) ability indicators Tree Thinking relating to understanding and reasons for using a phylogram or a phylogenetic tree, including: 1) Identifying the characters (synapomorphies) passed down by a common ancestor (MRCA /Most Recent Common Ancestor) and relate between 2 or more taxa, 2) Identify groups of taxa based on the same or unequal character in a typical character, 3) Understand the concept clade or monophyletic groups (ie groups consisting of MRCA and all their offspring), 4) Evaluating evolutionary relationships based on taxa groups, 5) Using supporting evidence about ancestral relationships between organisms, (Novick \& Catley, 2013). The next stage is categorization based on Arikunto (2010) as shown in Table 1.

Table 1. Category Percentage Value of The Thinking Tree for Each Indicator

\begin{tabular}{cc} 
Percentage & Predicate \\
\hline $81-100 \%$ & Very Good \\
$61-80 \%$ & Good \\
$41-80 \%$ & Average \\
$21-80 \%$ & Bad \\
$<21 \%$ & Very, very little
\end{tabular}

\section{RESULTS AND DISCUSSION}

Students' ability to learn tree thinking is expected to make a tree diagram cladogram/phylogenetic tree as a choice for students studying the classification and lineage of offspring in a species or order. According to Novick \& Catley (2013) observed indicators of ability tree thinking students on Arhtropoda material viewed from the percentage of each indicator, as in Table 2.

Table 2. Category Percentage Value of The Thinking Tree for Each Indicator

\begin{tabular}{|c|c|c|c|}
\hline & Indicator & $\begin{array}{l}\text { Average } \\
\text { score }\end{array}$ & Category \\
\hline Indicator 1 & $\begin{array}{l}\text { To determine shared character } \\
\text { (synapomorphies) passed down by a common } \\
\text { ancestor (MRCA/Most Recent Common } \\
\text { Ancestor) }\end{array}$ & $69 \%$ & Good \\
\hline Indicator 2 & $\begin{array}{l}\text { To determine the characteristics of groups of } \\
\text { animals }\end{array}$ & $63 \%$ & Good \\
\hline Indicator 3 & To determine monophyletic groups (klad) & $73 \%$ & Good \\
\hline Indicator 4 & $\begin{array}{l}\text { To determine the order in wich animals } \\
\text { appeared (evolution) from primitif to advance }\end{array}$ & $81 \%$ & $\begin{array}{l}\text { Very } \\
\text { Good }\end{array}$ \\
\hline Indicator 5 & $\begin{array}{l}\text { To determine evolutionary relationships } \\
\text { (close and distant relatives) }\end{array}$ & $52 \%$ & Average \\
\hline
\end{tabular}


The data above can be categorized as ability of tree-thinking class X students of SMA Negeri Sukabumi who have a good category. The category is based on Arikunto (2010), as shown in Table 1. The data's details of students' ability to understand tree thinking are seen from the percentage of each indicator. Addressing that, students better understand indicators 4 of 5 . The fourth indicator, evaluating the evolutionary relationship based on taxa groups, with an average total value of each indicator reaching $81 \%$ is categorized very well. The good category includes the 3rd indicator, Understanding the concept clade or monophyletic group (i.e. the group consisting of MRCA and all their offspring) by $73 \%$, and the 1 st indicator is Identifying characters (synapomorphies) passed down by a common ancestor (MRCA /Most Recent Common Ancestor) and related between 2 taxa or more by $69 \%$ are categorized as good. The second indicator is Identifying taxa groups based on the same or not the same characters in the typical characters as $63 \%$ are categorized well. Whereas in the category sufficient is the 5th indicator that is using evidence that supports the ancestral relationship between organisms by $52 \%$. Increasing the value of mastery of students' concepts of arthropod calcification material by learning to use phylogenetic trees, this fact is following the research conducted by Catley et al., (2013), which aims to see competence tree thinking high school students in the United States and report how students experience increased cognitive abilities with phylogenetic tree representation.

Students' ability to learn tree thinking or phylogenetic tree from the results of the percentage of the average indicator shows that students in studying this phylogenetic tree require habituation in learning how to classify or find out the ancestral lineage of an order species using a tree diagram (phylogenetic). Students' understanding of the five indicators tree thinking taught, it turns out students understand better the 4th indicator, which is to find out and determine the order in which animals (evolution) appear from primitive to advanced. That is because students are more interested in finding out the origin or lineage of a species. The lack of students' understanding of the 5th Kadik indicator is because students find it challenging to understand tree readings to determine the evolutionary relationship (close and distant relatives). This condition is presumably because students still feel unfamiliar with the situation where relatives are near and far from a species or order on the arthropod classification material. Indicators that are high enough are the average values; indicators 1, 2, and 3. This condition is because students feel not too familiar with these indicator terms.

Learn tree thinking or phylogenetic tree requires understanding to read the phylogenetic tree itself because most students do not understand how to read phylogenetic 
trees, so students often find it difficult to answer questions on an indicator think is very complicated. Learn tree thinking or phylogenetic trees students should not be taught just one time learning, because making phylogenetic trees requires habituation of approximately 2 or three times of learning with different materials. There are examples of subjects that can use phylogenetic trees, including the material: (Plantae, Animalia, Evolution, Microbiology, etc.) related to the classification or history of evolution. A study conducted by Dees et al., (2014) revealed that learning using phylogenetic trees could directly affect students' understanding of the evolution of a taxa group. However, understanding the evolution of the concept of arthropod classification is not easy because if it is taught only once, students often find it difficult to read the phylogenetic tree- the need for practice to make students better understand the sentences in the tree reading.

Learning outcomes are essential in the learning process to provide teachers with information about the progress of their students in achieving learning goals. Student learning outcomes in studying phylogenetic trees on arthropod material are quite varied. Based on Mahbubah (2017) research, students are more interested in using animals rather than plants in learning the concept of evolution. Therefore most students experience a significant increase in grades, but some students get low scores, this increase in mastery values is expected because students have different catches and different seriousness of learning. Even though the learning process has been done, there are still students who get low grades. The low ability of students to study phylogenetic trees is thought to be due to low learning interest. Students' interest in learning the concept of classification is very lacking even though the ability to classify is a basic ability that someone possesses. The importance of this is not in line with how the learning process occurs in general at school. The classification learning process in most schools seems boring. This condition can occur because of the way teachers delivered the material during the learning process and the limitations of the media. One of the essential parts in the world of biology education is taxonomy and evolution, at the level of primary education, secondary education, and higher education. With the designated modifications following their intellectual development, there is a tendency of students towards material related to taxonomy and evolution, which is still low because their views on this material are memorized, theoretical, and tend to be boring (Hidayat, 2017). Therefore it takes a high interest and active student learning by using phylogenetic trees in studying classification. The more students are active in the classroom and have a high interest in learning, then their learning persuasion will increase, meaning that the better or higher the level of student interest in learning, the better the results or their learning 
achievement. Conversely, decreased or low learning achievement can occur if student awareness to increase interest in learning is still lacking or can be said as low learning interest (Darajaad, 2016).

\section{CONCLUSION}

Based on the results of the research, to conclude that the profile of students' tree thinking emergence on each indicator is in good or increasing category. This study suggests that the IBL model can be used as an alternative in learning biology to improve tree thinking skills.

\section{ACKNOWLEDGMENT}

The researchers' gratitude goes to all those who have helped both morally and materially in this study.

\section{REFERENCE}

Ali, M. (2010). Metodologi dan aplikasi riset pendidikan. Pustaka Cendekia Utama.

Anjarsari, P. (2014). Literasi sains dalam kurikulum dan pembelajaran IPA SMP. Prosiding Semnas Pensa VI" Peran Literasi Sains" Surabaya, 20.

Arikunto, S. (2010). Prosedur Penelitian Suatu Pendekatan Praktik. 2010. Jakarta: Rineka Cipta.

Baum, D. A., \& Offner, S. (2008). Phylogenies \& tree-thinking. The American Biology Teacher, 70(4), 222-229.

Catley, K. M., Phillips, B. C., \& Novick, L. R. (2013). Snakes and eels and dogs! Oh, my! Evaluating high school students' tree-thinking skills: An entry point to understanding evolution. Research in Science Education, 43(6), 2327-2348.

Darajaad, R. (2016). Pengaruh Minat Belajar Dan Jam Belajar Terhadap Prestasi Belajar Siswa Pada Mata Pelajaran Ekonomi Di Siswa Kelas XI IPS 3 SMA Negeri 1 Kesamben Kabupaten Jombang. Jurnal Pendidikan Ekonomi (JUPE), 4(3).

Dees, J., Momsen, J. L., Niemi, J., \& Montplaisir, L. (2014). Student interpretations of phylogenetic trees in an introductory biology course. CBE-Life Sciences Education, 13(4), 666-676.

Hidayat, T. (2017). Menggairahkan pembelajaran taksonomi di kelas menggunakan metode fenetik. Retrieved October, 7, 2017.

Jones Jr, S. B., \& Luchsinger, A. E. (1986). Plant systematics. McGraw-Hill. 
Jurnal Mangifera Edu, Volume 5, Nomor 1, Juli 2020, 18-25

Kemendikbud. (2016). Peraturan Menteri Pendidikan dan Kebudayaan No 24 Tahun 2016 Tentang Kompetensi Inti dan Kompetensi Dasar Pelajaran pada Kurikulum 2013 pada Pendidikan Dasar dan Pendidikan Menengah. Jakarta: Kemendikbud.

Mahbubah, H. G. (2017). Analisis Kemampuan Tree Thinking Mahasiswa yang Menggunakan Hewan dan Tumbuhan sebagai Model dalam Pembelajaran Evolusi. Thesis. Universitas Pendidikan Indonesia.

Novick, L. R., \& Catley, K. M. (2007). Understanding phylogenies in biology: The influence of a Gestalt perceptual principle. Journal of Experimental Psychology: Applied, 13(4), 197.

Novick, L. R., \& Catley, K. M. (2013). Reasoning about evolution's grand patterns: College students' understanding of the tree of life. American Educational Research Journal, 50(1), 138-177.

Novick, L. R., \& Catley, K. M. (2016). Fostering 21st-century evolutionary reasoning: teaching tree thinking to introductory biology students. CBE-Life Sciences Education, 15(4), ar66.

Novick, L. R., \& Catley, K. M. (2018). Teaching tree thinking in an upper level organismal biology course: Testing the effectiveness of a multifaceted curriculum. Journal of Biological Education, 52(1), 66-78.

Sudjana, N. (2007). Penelitian dan Penilaian Pendidikan. Bandung: Sinar Baru Algensindo.

Wiley, E. O., \& Lieberman, B. S. (2011). Phylogenetics: theory and practice of phylogenetic systematics. John Wiley \& Sons. 